\title{
Geochemistry of basaltic ash beds from the Fur Formation, Island of Fur, Denmark
}

\author{
ANDREW C. MORTON AND JANE A. EVANS
}

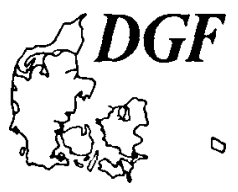

\begin{abstract}
Morton, A. C. \& Evans, J. A.: Geochemistry of basaltic ash beds from the Fur Formation, Island of Fur, Denmark, Bull. geol. Soc. Denmark, Vol. 37, pp. 1-9, Copenhagen, October 14th, 1988. https://doi.org/1037570/bgsd-1988-37-01

The major, trace, rare earth and strontium isotopic compositions of five ash layers of Early Eocene age from Knudeklint, Fur (Denmark) have been determined in order to establish the geochemical nature of the magmas and, particularly, to provide geochemical constraints on the source. The sample set includes some layers reported to show systematic local grain size and thickness variations $(+51$ and + $114)$ as well as layers that apparently lack such variations $(+1,+35$ and +60$)$. Despite these differences, the five layers have remarkably similar compositions, apart from showing a limited degree of fractionation, and are therefore believed to have a common source. The magmas sourcing the eruptions were of continental tholeiite type, comparable to the early Tertiary basalts of the Faeroes-East Greenland province. Var-iations in initial ${ }^{87} \mathrm{Sr} /{ }^{86} \mathrm{Sr}$ ratio appear to correlate with $\mathrm{SiO}_{2}$, suggesting that small amounts of continental crustal material may have assimilated by the tholeiitic magma prior to eruption.
\end{abstract}

A. C. Morton, British Geological Survey, Keyworth, Notts NG12 5GG, UK. J. A. Evans, British Geological Survey, 64 Grays Inn Rd., London WCIX 8NG, UK. August 7th, 1987.

\section{Introduction}

The numerous beds of volcanic ash within early Tertiary sediments of Denmark were first recognised by Prinz \& Van Ermengen (1883), and have been the subject of much attention subsequently. Approximately 200 ash layers have been recognised, most of which have been numbered (Bøggild, 1918). The sequence is broadly divisible into two, the "negative series", comprising ash layers -39 to -1 , and the overlying "positive series" comprising layers 1 to 140 . Pedersen \& Jørgensen (1981) have identified four distinct stages of volcanism in the sequence, with Stage 1 ( -39 to -21) comprising mainly tholeiites with subordinate rhyolites, Stage $2(-21$ to -14$)$ containing mafic and salic alkaline tephras as well as those of basaltic composition, Stage $3(-13$ to +19$)$ consisting mainly of tholeiitic tephras, but again with subordinate rhyolites, and Stage $4(+20$ to +140$)$ comprising exclusively Fe-Ti tholeiites. Recent palynological studies indicate that the maximum phase of explosive activity, as recorded by the positive series (Stage 4 of Pedersen \& Jørgensen 1981), is of latest Palaeocene or earliest Eocene age (Heilmann-Clausen, Nielsen \& Gersner, 1985). Knox (1984) inferred an Early Eocene age (nannoplankton Zone NP10) by correlation with bentonites of similar composition in the NE At- lantic, believed to be the distal equivalents of the Danish ash series.

From an early stage, it has been known that the majority of the ash beds, particularly those of the positive series, are of basaltic composition (Bøggild, 1918). The only rigorous geochemical study of the ash beds, however, is that of Pedersen, Engell \& Rønsbo (1975), who determined contents of major elements by electron microprobe analysis of glass shards from the sequence on the Island of Fur (Fig. 1). At this locality, the basaltic ashes have been protected from extensive alteration by virtue of being interbedded with diatomite. Pedersen et al. (1975) also presented a limited suite of trace element data from two of the basaltic ash layers $(+22,+51)$. Textural studies indicate that phreatomagmatic (Surtseyan) activity was responsible for the basaltic tephras (Pedersen \& Jørgensen 1981).

The Danish ash series has been regarded by many authors (Bøggild, 1918; Andersen, 1937; Norin 1940; Pedersen et al., 1975; Nielsen \& Heilmann-Clausen, 1988) as having been sourced locally, from volcanoes sited in the Skagerrak. A volcanic centre in the Skagerrak has been identified on geophysical grounds (Am, 1973) and subsequent dredging has confirmed the presence of basaltic rocks at the sea bed in the area (Hovland 1987). A local Skagerrak source has been in- 


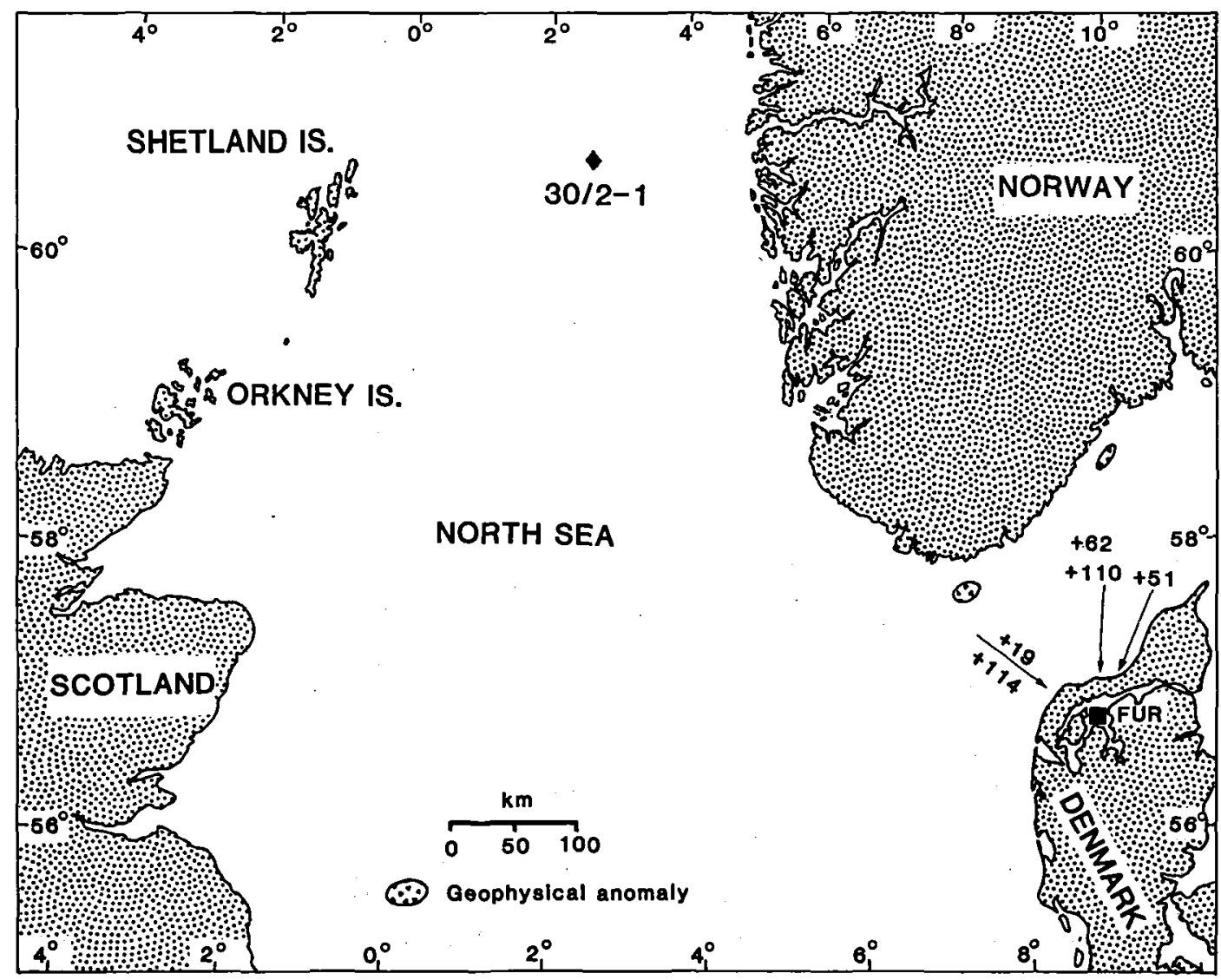

Figure 1. Location map showing Fur and Norwegian well 30/2-1, geophysical anomalies in the Skagerrak interpreted as Tertiary igneous rocks by Am (1973), and transport directions inferred for ash layers +51 and +114 . Ash layers $+1,+35$ and +60 do not show consistent grain size and thickness trends, precluding an assessment of their transport directions.

ferred on the basis of grain size and thickness variations of a few of the layers (principally +19 , $+51,+62,+110,+114)$; the remainder apparently show little or no systematic variation. Although a Skagerrak source appears to be perfectly reasonable in a purely Danish context, the extremely widespread distribution of correlative basaltic tuffs southward into northern Germany (Gagel, 1907) and NW Holland (Pannekoek, 1956), southwestward to SE England (Knox \& Ellison, 1979) and the NE Atlantic (Knox, 1984), and, particularly important, westward and northwestward over the entire North Sea Basin (Knox \& Morton, 1983), extending into the area west of Shetland (Hitchen \& Ritchie, 1987) argues for another source, located in the NE Atlantic. The overall increase in total ash thickness in a northwestward direction away from Denmark (Knox \& Morton, 1988) clearly indicates that a Skager- rak source, if operative at all, was of relatively minor importance.

In view of the dispute over the relative importance of contributions form the Skagerrak and more distant sources, detailed whole-rock geochemical studies of five of the ash layers have been carried out. The aim of the study was to determine the nature of the basaltic ashes and in particular, to identify characteristics that might help to establish the source area. The ashes that were selected for study are $+1,+35,+51,+60$ and +114 . They were collected by Dr R W O'B Knox (BGS) and Dr O B Nielsen (Aarhus University) from the section at Knudeklint, on the Island of Fur. Two of the layers $(+51,+114)$ show systematic grain size variations that indicate transport directions from the NE and NW respectively (Andersen, 1937): the other three have not been reported as showing systematic trends. 
Trace element contents from one of these layers $(+51)$ have been determined by Pedersen et al. (1975), allowing a direct comparison to be made. All consist predominantly of vitric particles, either brown ("sideromelane") or black ("tachylite"). The brown shards are isotropic, indicating that post-depositional processes have not caused extensive hydration and alteration. Lithic particles (commonly with microlitic texture) and crystal fragments (mainly calcic plagioclase with minor clinopyroxene) form less than $5 \%$ of the pyroclasts.

\section{Major and trace element geochemistry}

Major and trace element contents of the five ash layers were determined by X-ray fluorescence by Dr P Harvey and Dr B Atkin (Nottingham University), and rare earth element, Th, Ta and $\mathrm{Hf}$ concentrations were determined by neutron activation (INAA) by Dr I Sinclair at the Imperial College Reactor Centre. Major, trace and rare earth element data are given in Table 1. Also shown in Table 1 are trace element contents determined by Pedersen et al. (1975) for ash layer +51 . The two data sets are closely comparable, with only $\mathrm{Cr}$ values being markedly different:

Although +51 and +114 differ from the others in showing systematic regional variations in grain size and thickness, all five layers have remarkably

Figure 2. Ternary discriminant diagrams

2A: The Ti-Zr-Y diagram devised by Pearce \& Cann (1973). The five layers plot in a tight cluster in field $D$ (within-plate basalt). Low potassium tholeiites fall in fields $A$ and $B$, calcalkali basalts in fields $B$ and $C$, and ocean floor basalts in field B.

2B: The Ta-Th-Hf diagram devised by Wood et al. (1979). The five layers cluster in the centre of field B (E-type mid-ocean ridge basalt and within plate basalt). Field $A$ is $\mathrm{N}$-type midocean ridge basalt, field $C$ is within-plate basalt, and field $D$ is for magma series at destructive plate boundaries.

2C: The Nb-Zr-Y plot devised by Meschede (1986). The Danish ashes (closed circles) cluster across the boundary between fields A (within-plate tholeiite and within-plate alkali basalt) and field $C$ (within-plate tholeiite), indicating a within-plate tholeiite source for the explosive volcanism. Field B represents Etype MORB, field D is N-type MORB. The altered Balder Fm. tuffs (chronologically equivalent to the Danish ash series) from Norwegian well 30/2-1 (open circles) show a good clustering, adjacent to, but not overlapping, the field covered by the five Danish ashes.
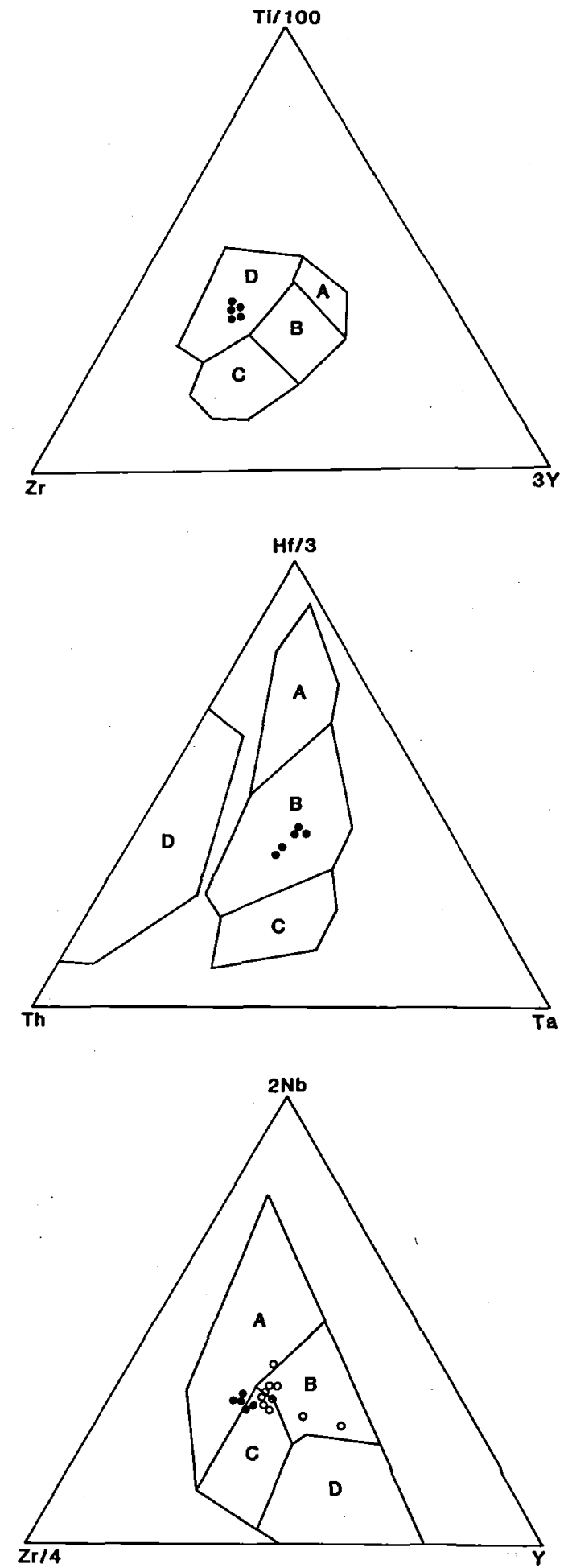
Table 1. Geochemistry of five Danish ashes from the Early Eocene of Knudeklint, Island of Fur, Denmark.

\begin{tabular}{|c|c|c|c|c|c|}
\hline & +1 & +35 & +51 & +60 & +114 \\
\hline $\mathrm{SiO}_{2}$ & 49.03 & 49.16 & 50.52 & 49.90 & 51.02 \\
\hline $\mathrm{Al}_{2} \mathrm{O}_{3}$ & 11.89 & 12.15 & 12.60 & 12.59 & 12.27 \\
\hline $\mathrm{TiO}_{2}$ & 3.45 & 3.31 & 3.36 & 3.22 & 3.66 \\
\hline $\mathrm{Fe}_{2} \mathrm{O}_{3}$ & 15.98 & 15.44 & 14.46 & 15.23 & 15.97 \\
\hline $\mathrm{MgO}$ & 4.20 & 4.47 & 4.03 & 4.62 & 3.64 \\
\hline $\mathrm{CaO}$ & 8.21 & 8.40 & 7.28 & 8.69 & 6.89 \\
\hline $\mathrm{Na}_{2} \mathrm{O}$ & 2.38 & 2.94 & 2.86 & 2.95 & 2.34 \\
\hline $\mathrm{K}_{2} \mathrm{O}$ & 0.68 & 0.71 & 0.67 & 0.72 & 0.74 \\
\hline $\mathrm{MnO}$ & 0.19 & 0.21 & 0.18 & 0.20 & 0.20 \\
\hline $\mathrm{P}_{2} \mathrm{O}_{5}$ & 0.35 & 0.36 & 0.51 & 0.39 & 0.38 \\
\hline LOI & 3.67 & 2.68 & 3.54 & 1.61 & 3.03 \\
\hline Total & 100.01 & 99.82 & 100.13 & 100.02 & 100.15 \\
\hline $\mathbf{B a}$ & 277 & 265 & $234(200)$ & 219 & 286 \\
\hline $\mathrm{Cr}$ & 120 & 81 & $90(66)$ & 88 & 70 \\
\hline $\mathrm{Cu}$ & 233 & 228 & 203 & 250 & 282 \\
\hline $\mathrm{Nb}$ & 23 & 24 & $25(28)$ & 24 & 26 \\
\hline $\mathrm{Ni}$ & 49 & 52 & $50(53)$ & 49 & 57 \\
\hline $\mathrm{Pb}$ & 2 & 3 & 5 & 3 & 5 \\
\hline $\mathbf{R b}$ & 13 & 12 & 13 & 14 & 13 \\
\hline Sc & 31 & 37 & 39 & 33 & 39 \\
\hline $\mathrm{Sr}$ & 292 & 281 & $268(260)$ & 275 & 224 \\
\hline V & 397 & 394 & $367(390)$ & 370 & 388 \\
\hline $\mathbf{Y}$ & 37 & 40 & 40 & 44 & 48 \\
\hline$Z_{n}$ & 129 & 124 & 113 & 130 & 131 \\
\hline $\mathrm{Zr}$ & 247 & 235 & $258(250)$ & 248 & 289 \\
\hline $\mathbf{L a}$ & 18.7 & 22.4 & 21.5 & 24.4 & 23.1 \\
\hline $\mathrm{Ce}$ & 47.4 & 50.0 & 48.6 & 55.2 & 59.8 \\
\hline Nd & 34.1 & 39.0 & 38.2 & 41.4 & 47.7 \\
\hline $\mathrm{Sm}$ & 7.11 & 8.06 & 8.12 & 8.65 & 10.4 \\
\hline Eu & 2.37 & 2.66 & 2.55 & 2.77 & 3.25 \\
\hline $\mathrm{Tb}$ & 1.16 & 1.27 & 1.21 & 1.39 & 1.60 \\
\hline $\mathrm{Yb}$ & 2.81 & 2.93 & 3.11 & 3.31 & 4.29 \\
\hline Lu & 0.36 & 0.44 & 0.37 & 0.49 & 0.55 \\
\hline Ta & 2.03 & 1.99 & 1.85 & 1.87 & 1.92 \\
\hline Th & 2.45 & 1.68 & 2.20 & 1.85 & 1.82 \\
\hline $\mathrm{Hf}$ & 7.06 & 7.17 & 6.56 & 7.05 & 7.60 \\
\hline
\end{tabular}

Major elements expressed as weight $\%$, trace elements in ppm. Major and trace elements analyses by XRF, rare earth elements and $\mathrm{Ta}, \mathrm{Th}$ and Hf by INAA. Figures in brackets refer to data from Pedersen et al. (1975) for comparison.

similar compositions. This can be demonstrated on triangular plots such as the Ti-Zr-Y plot (Fig. 2A), the Ta-Th-Hf plot (Fig. 2B) or the Zr-Nb-Y plot (Fig. 2C), or on multi-element plots such as the mid-ocean ridge basalt (MORB)-normalised spidergram (Fig. 3) or the chondrite-normalised rare earth plot (Fig. 4).

On the Ti-Zr-Y plot (Fig. 2A) of Pearce \& Cann (1973), the five samples plot in a tight cluster in the within-plate basalt field. On the TaTh-Hf plot (Fig. 2B) of Wood, Joron \& Treuil (1979) they cluster in the centre of the E-type MORB + within-plate basalt field. Similarly, they cluster together on the $\mathrm{Zr}-\mathrm{Nb}-\mathrm{Y}$ diagram (Fig. 2C) of Meschede (1986) in the within-plate tholeiite field. However, their close similarity is perhaps best demonstrated by multi-element plots. The five samples display virtually identical patterns on the MORB-normalised spidergram (Fig. 3), showing characteristic negative $\mathrm{Sr}$ anomalies, positive $\mathrm{Nb}$ and $\mathrm{Ta}$ anomalies, and progressive decline of $\mathrm{Tb}, \mathrm{Y}$ and $\mathrm{Yb}$ with respect to $\mathrm{N}$-type MORB. Apart from Sr, the elements from $\mathrm{Rb}$ to $\mathrm{Ce}$ (LIL elements), plus $\mathrm{Nb}$ and $\mathrm{Ta}$, display a 5- to 20-fold enrichment with respect to $\mathrm{N}$-type MORB. The remaining HFS elements as far as Ti form a plateau at about $3 \times$ MORB, with $\mathrm{Tb}$ at about $2 \times$ MORB and $\mathrm{Y}$ and $\mathrm{Yb}$ approximately at MORB values. On the chondrite-normalised rare-earth plot (Fig. 4), the samples show parallel trends of strong light REE enrichment, although $\mathrm{La}, \mathrm{Ce}$ and $\mathrm{Nd}$ form a plateau.

Variations in incompatible elements such as $\mathrm{Ti}$ are related to fractionation processes: $\mathrm{TiO}_{2}$ values (corrected volatile-free) correlate excellently with $\mathrm{FeO}^{*} / \mathrm{MgO}$ (Fig. 5), indicating that this ratio is apparently unaffected by alteration processes.

The compositional similarity of the five ashes is also demonstrated by their comparable $\mathrm{Ce}$ and $\mathrm{Yb}$ values (Fig. 6) and their similar $\mathrm{La} / \mathrm{Ta}$ ratios. These parameters, together with the Ta-Th-Hf and $\mathrm{Nb}-\mathrm{Y}-\mathrm{Zr}$ discriminant plots (Figs $2 \mathrm{~B}$ and $2 \mathrm{C}$ ), are of particular value in a petrogenetic context. On the $(\mathrm{Ce})_{N}-(\mathrm{Ce} / \mathrm{Yb})_{N}$ crossplot of Saunders (1984), the five layers plot in the E-type MORB field. However, because Ce values may also be affected by fractional crystallization processes, ratios of highly incompatible elements $\mathrm{La}$ and $\mathrm{Ta}$ are believed by Saunders (1984) to be better indicators of mantle source. The mean $\mathrm{La} / \mathrm{Ta}$ ratio for the five ashes is 11.4 , with a range from 9.2 to 13.0, confirming an enriched mantle source. An enriched mantle source is also suggested by the position of the ashes in the E-type MORB + WPB field of the Ta-Th-Hf ternary diagram. The positive Nb-Ta anomaly seen on the MORB-normalised spidergram (Fig. 3) is another characteristic of an enriched mantle source, interpreted by Saunders \& Tarney (1983) as due to metasomatic re-enrichment of the upper mantle from the lower mantle. However, despite their enriched nature, the ashes are tholeiitic: as noted by Pedersen et al. (1975), they are all hypersthenenormative, and several are additionally quartz- 


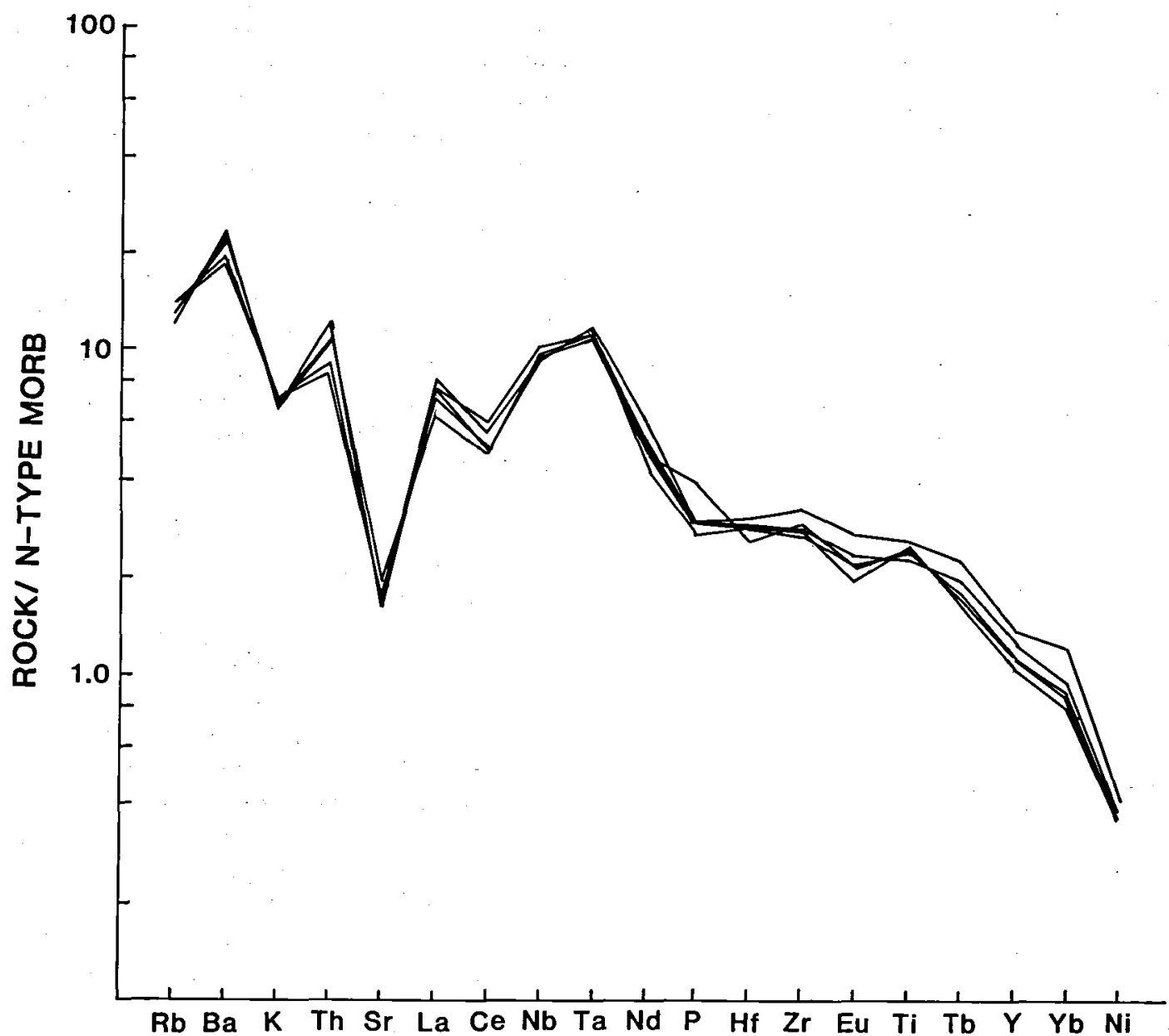

Figure 3. Spidergram of the five Danish ashes normalised to N-type MORB, using the normalising data of Saunders \& Tarney (1983). The five samples bear strong similarities to each other, demonstrating their common source. Note the strong $\mathrm{Nb}-\mathrm{Ta}$ anomaly and the decline in $\mathrm{Tb}, \mathrm{Y}$ and $\mathrm{Yb}$ relative to $\mathrm{N}$-type MORB.

normative. Their tholeiitic nature is also indicated by their $\mathrm{Nb} / \mathrm{Y}$ ratio, which ranges from 0.54 to 0.63 , with a mean of 0.59 . Enriched tholeiitic basalts are typical of continental flood basalt regimes, and this is further indicated by the ternary discriminant $\mathrm{Nb}-\mathrm{Y}-\mathrm{Zr}$ diagram (Fig. 2C), in which the ashes plot in the within-plate tholeiite field.

\section{Strontium isotope geochemistry}

Strontium was separated from the five samples using standard techniques of mixed acid digestion and ion exchange column chemistry. The isotopic composition of the strontium was determined using a VG 354 automated mass spectrometer which, during the year in which the analyses were made, produced a mean value of $0.710223 \pm$ 0.000033 for 137 analyses of the international standard NBS 987 . Rb and Sr contents were determined by XRF (Table 1). The errors on these values are $\pm 12.5 \%$ ( 1 sigma) and $\pm 1 \%$ (1 sigma) respectively, resulting in errors of about $12.5 \%$ (1 sigma) on the $\mathrm{Rb} / \mathrm{Sr}$ ratio. Initial ${ }^{87} \mathrm{Sr} /{ }^{86} \mathrm{Sr}$ ratios were calculated at $55 \pm 1.5 \mathrm{Ma}$ (1-sigma), the $\mathrm{Pa}$ laeocene-Eocene boundary, using the decay constant for ${ }^{87} \mathrm{Rb}$ recommended by Steiger \& Jäger (1977).

Strontium isotopic data are shown in Table 2. 


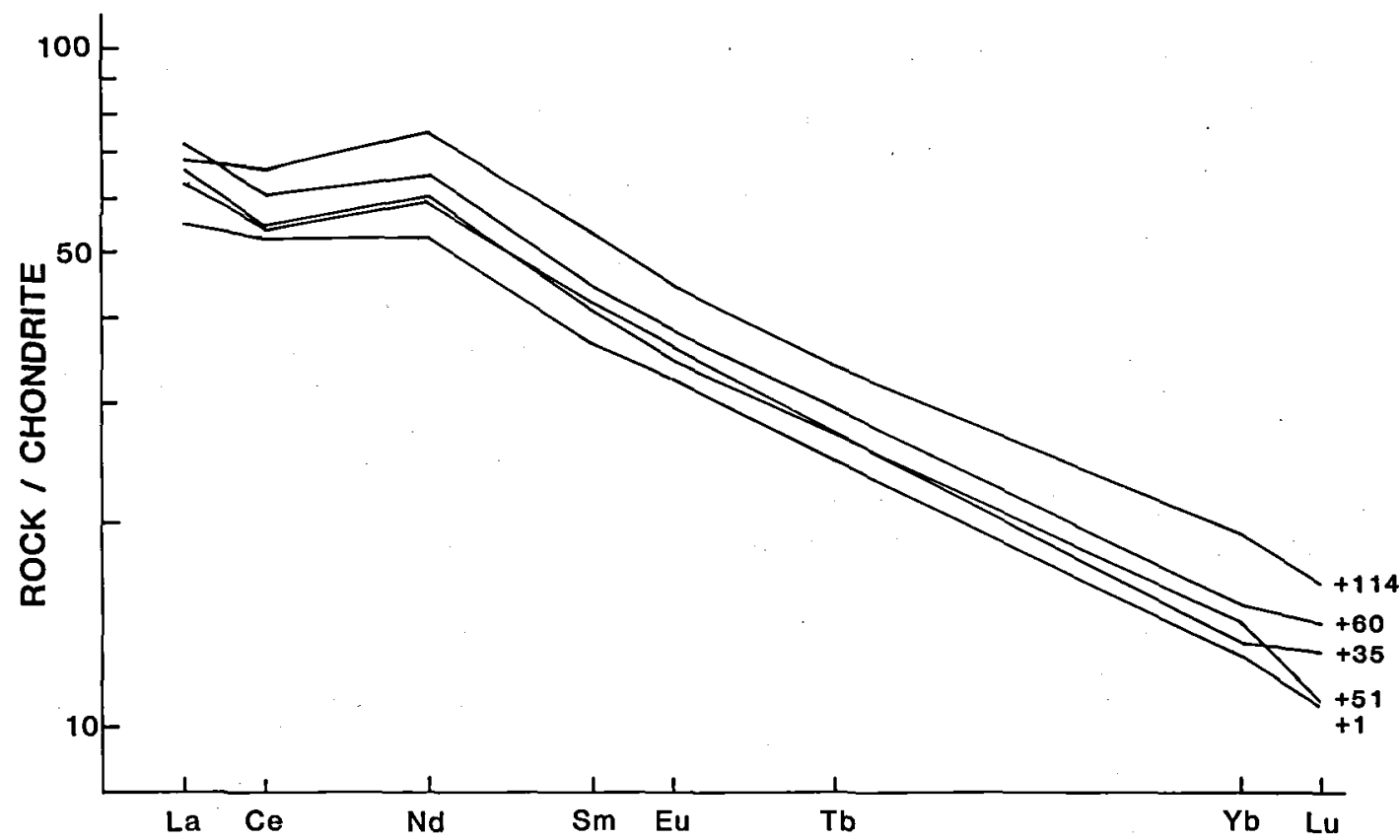

Figure 4. Chondrite-normalised rare earth plot of the five Danish ashes. The five samples show strong light rare earth enrichment, although the lightest ( $\mathrm{La}, \mathrm{Ce}$ and $\mathrm{Nd}$ ) form a plateau. Note the tendency for higher overall REE contents with stratigraphic height.

Measured ${ }^{87} \mathrm{Sr} /{ }^{86} \mathrm{Sr}$ ratios lie between 0.70406 and 0.70451 , with calculated initial ${ }^{87} \mathrm{Sr} /{ }^{86} \mathrm{Sr}$ ratios falling between 0.70396 and 0.70462 . These are within the range of mantle values and are consistent with an enriched mantle source.

Although the data fall into a relatively narrow

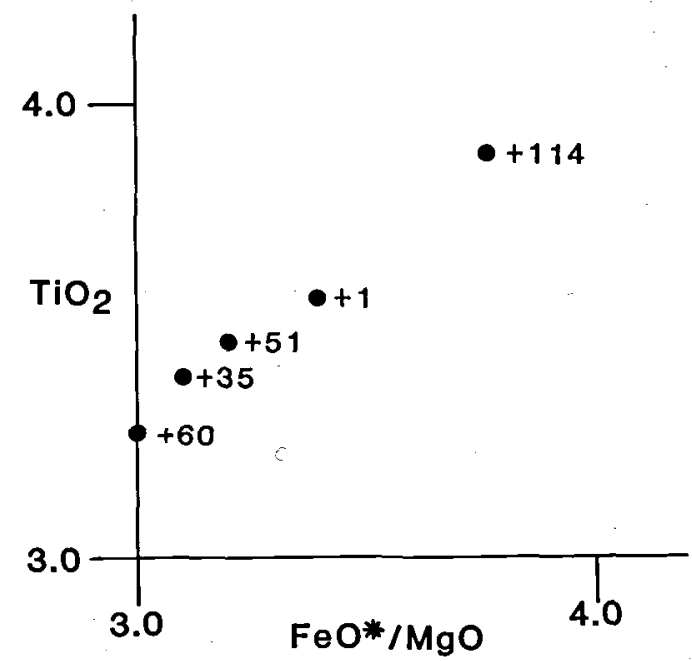

Figure 5. Crossplot of the two fractionation indices $\mathrm{TiO}_{2}$ and $\mathrm{FeO}^{*} / \mathrm{MgO}$, showing evidence for a limited degree of fractionation within the sequence. Ash +114 , the stratigraphically highest tephra included in the study, is also the most evolved. range there are some variations. Interaction with seawater and/or meteoric waters are among the possible causes. Seawater ${ }^{87} \mathrm{Sr} /{ }^{86} \mathrm{Sr}$ ratios ranged from 0.7076 to 0.7090 during the Tertiary (Burke et al., 1982), and meteoric water values are likely

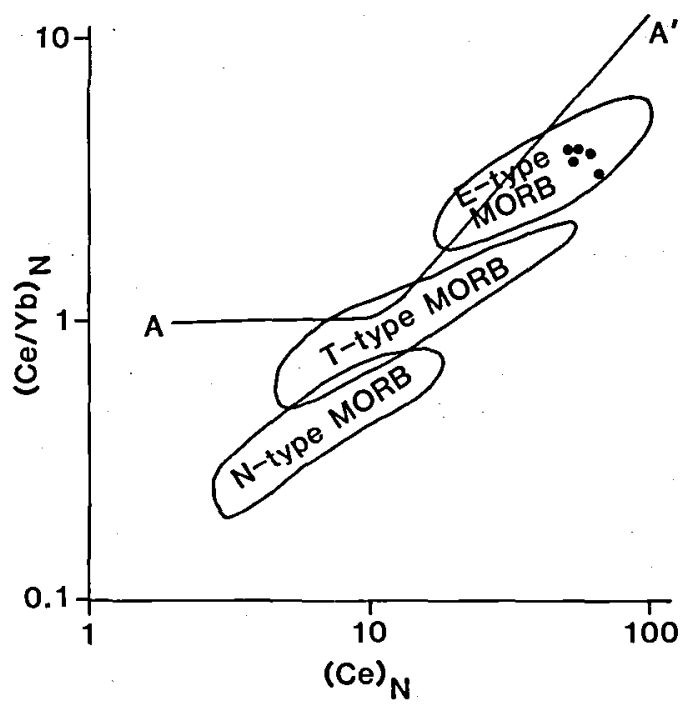

Figure 6. Crossplot of $(\mathrm{Ce})_{N}$ and $(\mathrm{Ce} / \mathrm{Yb})_{N}$. The five layers cluster strongly in the E-type MORB field. A-A' represents dynamic partial melting curve of a mantle source with $(\mathrm{Ce})_{\mathrm{N}}=$ 2 and $(\mathrm{Ce} / \mathrm{Yb})_{\mathrm{N}}=1$, after Saunders (1984). 
Table 2. Strontium isotopic compositions of five ash layers from the early Eocene of Knudeklint, Island of Fur, Denmark.

\begin{tabular}{lllllll}
\hline & Rb & $\mathrm{Sr}$ & $\mathrm{Rb} / \mathrm{Sr}$ & ${ }^{87} \mathrm{Rb} /{ }^{86} \mathrm{Sr}$ & $\begin{array}{c}\text { measured } \\
{ }^{87} \mathrm{Sr} /{ }^{86} \mathrm{Sr}\end{array}$ & $\begin{array}{c}\text { initial } \\
{ }^{87} \mathrm{Sr}{ }^{86} \mathrm{Sr}\end{array}$ \\
\hline Ash +1 & 13 & 292 & 0.045 & 0.1288 & 0.70406 & 0.70396 \\
Ash +35 & 12 & 281 & 0.043 & 0.1235 & 0.70413 & 0.70404 \\
Ash +51 & 13 & 268 & 0.049 & 0.1403 & 0.70473 & 0.70462 \\
Ash +60 & 14 & 275 & 0.051 & 0.1472 & 0.70436 & 0.70425 \\
Ash +114 & 13 & 224 & 0.058 & 0.1678 & 0.70451 & 0.70438 \\
\hline
\end{tabular}

$\mathrm{Rb}$ and $\mathrm{Sr}$ values by XRF (see Table 1). Isotopic methods discussed in text.

to be somewhat higher: consequently, alteration through seawater or meteoric water interaction would cause a rise in the observed ${ }^{87} \mathrm{Sr} /{ }^{86} \mathrm{Sr}$ ratio. The effects of hydration can be crudely assessed by assuming that variation in loss on ignition values (LOI) reflect increased alteration. The poor correlation between initial ${ }^{87} \mathrm{Sr} /{ }^{86} \mathrm{Sr}$ and LOI (correlation coefficient $r=0.087$ ) indicates that the strontium isotopic variations probably did not result from seawater or meteoric water interaction. Neither does there appear to be a correlation between fractionation indices (such as $\mathrm{FeO}^{*} /$ $\mathrm{MgO}$ and initial ${ }^{87} \mathrm{Sr} /{ }^{86} \mathrm{Sr}$. However, the layers with the highest $\mathrm{SiO}_{2}$ values $(+51,+114)$ also have their highest initial ${ }^{87} \mathrm{Sr} /{ }^{86} \mathrm{Sr}$ (Fig. 7), suggesting that the $\mathrm{Sr}$ isotopic variations may be the result of assimilation of continental crustal material. This conclusion needs to be substantiated by a more detailed isotopic study of the ash series.

\section{Discussion}

Despite the fact that ash layers +51 and +114 appear, on the grounds of grain size and thickness variations, to be derived from the $N E$ and NW respectively, and that $+1,+35$ and +60 have not been recorded as showing systematic grain size or thickness trends, this geochemical study has shown that the five layers are closely related and were, beyond reasonable doubt, derived from the same source area, be it one or several source volcanoes. The geochemical data presented herein confirm the earlier suggestions of Pedersen et al. (1975) and Pedersen \& Jørgensen (1981) that the source magmas had affinities with continental flood basalts. Whilst a Skagerrak source cannot be ruled out on the basis of the present study, it seems unlikely that the Skager- rak was a site of continental flood basalt extrusion in the early Tertiary. A more logical source would be in the NE Atlantic, where basaltic magmatism was widespread during the early Tertiary (Morton \& Parson, 1988) and where enriched tholeiites of continental flood basalt type are widespread in the Faeroe-East Greenland province. $\mathrm{La}$ /Ta values for the Faeroes Lower Series, for example, average 13.5 (data of Gariepy, Ludden \& Brooks, 1983), comparable to the 11.4 recorded by the five Danish ashes. Knox \& Morton (1988) have suggested that local thickness variations, such as those shown by +51 and +114 , may be the result of drifting of suspended ash by prevailing water currents.

Before firm conclusions on the location of the source material can be drawn, however, it is necessary to establish whether the contemporaneous Balder Formation tuffs in the North Sea area have similar compositions. Little geochemical data is as yet available, the most extensive being the suite of major and trace element determinations by Malm et al. (1984) from the Balder Formation tuffs of Norwegian Well 30/2-1 (Fig. 1). Only seven trace elements were determined in this study, and consequently comparisons are difficult to make. However, the data set includes $\mathrm{Nb}, \mathrm{Y}$ and $\mathrm{Zr}$, and so the tuffs can be compared with the Danish ashes on the Nb-Y-Zr ternary plot (Fig. 2C). This shows the 30/2-1 tuffs plot in a tight cluster, apart from a little scatter toward

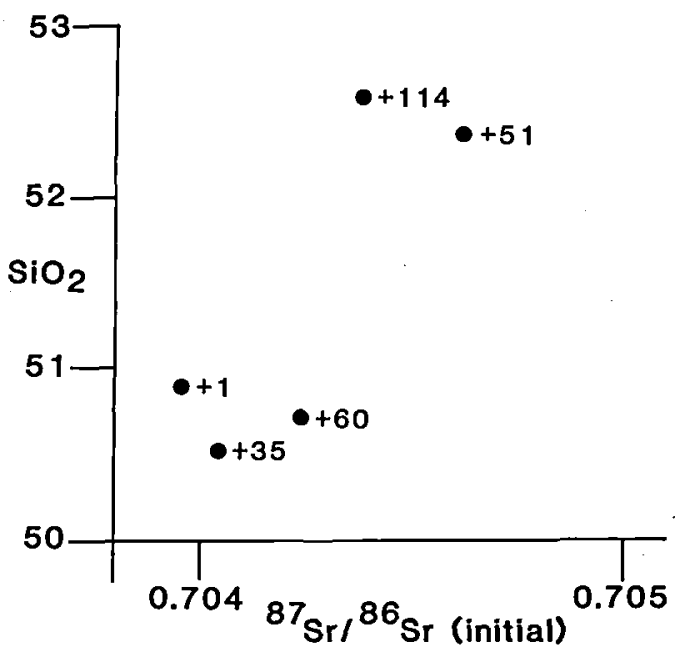

Figure 7. Crossplot of $\mathrm{SiO}_{2}$ (recalculated volatile-free) and initial ${ }^{87} \mathrm{Sr} /{ }^{86} \mathrm{Sr}$, suggesting a possible correlation between these parameters that would imply degree of continental crustal assimilation in the genesis of the magma supplying the tephras. 
the $\mathrm{Y}$ pole. The position of this cluster is adjacent to, but not overlapping, the field of the Danish ashes. This difference may be due to a number of factors:

(i) It may be a primary difference related to a different source.

(ii) It could reflect inter-laboratory variations.

(iii) The data base may not be sufficiently large, particularly the limited number of Danish ash samples.

(iv) The more advanced state of alteration of the North Sea material could have affected elemental abundances. Whilst $\mathrm{Nb}, \mathrm{Zr}$ and $\mathrm{Y}$ are held to be immobile, the North Sea tuffs are extensively and pervasively altered to clay minerals, pyrite, siderite, anatase and zeolite (Malm et al., 1984), and a limited degree of mobility is likely under such conditions.

Therefore, while it is apparent that the two series have similar compositions, it is not as yet clear whether the Danish ash series and the Balder tuffs of 30/2-1 had a common source. More extensive geochemical studies are in progress and will assess whether the Balder Formation tuffs over the North Sea area have a similar source to the Danish ashes. Preliminary results from the Balder tuffs of UK Well 16/7a-2 (Knox \& Morton, 1988) indicate that they are closely comparable to the Danish tephras, and it appears that the argument for a Skagerrak source will become extremely difficult to justify, in view of the general increase in total ash thickness northwestward away from Denmark (Knox \& Morton, 1988).

Acknowledgements. We are indebted to R. W. O'B. Knox and $O$. B. Nielsen for providing the samples. Discussion of the data by R. W. O'B. Knox and L. G. Viereck helped greatly with the preparation of the paper. We are grateful to $A$. K. Pedersen and $F$. Kalsbeek for their detailed and constructive reviews of the manuscript. This paper is published with permission of the Director, British Geological Survey (NERC).

\section{Dansk sammendrag}

Den kemiske sammensatning med hensyn til hoved-grundstoffer, sporstoffer, sjældne jordarters grundstoffer og strontium isotoper er blevet unders $\emptyset \mathrm{gt}$ i fem nedre eocæene askelag fra Fur Knudeklint. Undersøgelsen er foretaget med det formål at belyse den kemiske sammensxtning af magmaet og $i$ særdeleshed at indsnævre de mulige kilder.

Prøverne omfatter to $(n r .+51$ of +114$)$ der er kendt for at vise systematiske kornst $\varnothing$ rrelses- og tykkelses-variationer samt lag der tilsyneladende mangler en tilsvarende variation (nr. +1 , +35 og +60 ). På trods af forskellene, har de fem lag en be- mærkelsesværdig ensartet sammensætning, når man ser bort fra en begranset grad af fraktionering, hvorfor de antages at stamme fra samme kilde. Magmaerne bag udbruddene var af kontinental tholeiitisk type og er sammenlignelige med tidligt tertiære basalter fra Færøerne og $\emptyset_{\text {stgrønland. Variationer i }}$ strontium isotop forholdet korrelerer med $\mathrm{SiO}$ indholdet, hvilket peger pá, at mindre mængder af skorpemateriale er blevet assimileret i magmaet før udbruddene.

\section{References}

Am, K. 1973: Geophysical indications of Permian and Tertiary igneous activity in the Skagerrak. Nor. Geol. Unders., 287, $1-25$.

Andersen, S. A. 1937: De vulkanske askelag i vejskæringen ved Olst og deres udbredelse i Danmark. Dan. Geol. Unders., Rakke 2, 59, 53 pp.

Bøggild, O. B. 1918: Den vulkanske aske i Moleret samt en oversigt over Danmarks aldre Tertixrbjergarter, Dan. Geol. Unders., Rakke 2, 33, 159 pp.

Burke, W. H., Denison, R. E., Heatherington, E. A., Koepnick, R. B., Nelson, H. F. and Otto, J. B. 1982: Variation of seawater ${ }^{87} \mathrm{Sr} /{ }^{86} \mathrm{Sr}$ throughout Phanerozoic time. Geology, 10, 516-519.

Gariepy, C., Ludden, J. and Brooks, C. 1983: Isotopic and trace element constraints on the genesis of the Faeroe lava pile. Earth Planet. Sci. Lett., 63, 257-272.

Gagel, C. 1907: Über die untereozanen Tuffschichten und die paleozane Transgression in Norddeutschland. Jb. Königl. Preuss. Geol. Landesanst., 28, 150-168.

Heilmann-Clausen, C., Nielsen, O. B. and Gersner, F. 1985: Lithostratigraphy and depositional environments in the Upper Paleocene and Eocene of Denmark. Bull. Geol. Soc. Denmark, 33, 287-323.

Hitchen, K. and Ritchie, D. K. 1987: Geological review of the West Shetland area. In Brooks, J. \& Glennie, K. W. (eds): Petroleum Geology of North West Europe, 737-749. Graham \& Trotman, London.

Hovland, M. 1987: Tertiary intrusives in western Skagerrak? Mar. Geol., 78, 175-182.

Knox, R. W. O'B. 1984: Nannoplankton zonation and the Palaeocene/Eocene boundary beds of NW Europe: an indirect correlation by means of volcanic ash layers. J. Geol. Soc. Lond., 141, 993-999.

Knox, R. W. O'B. and Ellison, R. A. 1979: A Lower Eocene ash sequence in SE England. J. Geol. Soc. Lond., 136, 251-253.

Knox, R. W. O'B. and Morton A. C. 1983: Stratigraphical distribution of early Palaeogene pyroclastic deposits in the North Sea Basin. Proc. Yorks. Geol. Soc., 44, 355-363.

Knox, R. W. O'B. and Morton, A. C. 1988: The record of early Tertiary North Atlantic volcanism in sediments of the North Sea Basin. In Morton, A. C. \& Parson, L. M. (eds): Early Tertiary volcanism and the opening of the NE Atlantic. Spec. Pub. Geol. Soc. Lond., 39, 407-419.

Malm, O. A., Christensen, O. B., Furnes, H., Løvlie, R., Rueslatten, H. and Østby, K. L. 1984. The Lower Tertiary Balder Formation: an organogenic and tuffaceous deposit in the North Sea region. In Spencer, A. M. et al. (eds): Petroleum geology of the North European margin, 149 170. Graham \& Trotman, London.

Meschede, M. 1986: A method of discriminating between different types of mid-ocean ridge basalts and continental tholeiites with the Nb-Zr-Y diagram. Chem. Geol., 56, 207-218. 
Morton, A. C. and Parson, L. M. (eds) 1988: Early Tertiary volcanism and the opening of the NE Atlantic. Spec. Pub. Geol. Soc. Lond., 39.

Nielsen, O. B. and Heilmann-Clausen, C. 1988: Palaeogene volcanism: the sedimentary record in Denmark. In Morton, A. C. \& Parson, L. M. (eds): Early Tertiary volcanism and the opening of the NE Atlantic. Spec. Pub. Geol. Soc. Lond., 39, 395-405.

Norin, R. 1940: Problems concerning the volcanic ash layers of the lower Tertiary of Denmark. Geol. Foren. Stockh. Forh., 62, 31-44.

Pannekoek, A. J. 1956: Geological History of the Netherlands. s' Gravenhage (Staatsdrukkerij en Uitgverijbedrijf), 147 pp.

Pearce, J. A. and Cann, J. R. 1973: Tectonic setting of basic volcanic rocks determined using trace element analysis. Earth Planet. Sci. Lett., 19, 290-300.

Pedersen, A. K., Engell, J. and Rønsbo, J. G. 1975: Early Tertiary volcanism in the Skagerrak: New chemical evidence from ash-layers in the mo-clay of northern Denmark. Lithos, 8, 255-268.

Pedersen, A. K. and Jørgensen, K. A. 1981: A textural study of basaltic tephras from lower Tertiary diatomites in northern Denmark. In Self, S. \& Sparks, R. S. J. (eds): Tephra studies, 213-218. Reidel, Dordrecht.

Prinz, W. and Van Ermengem, E. 1883: Recherches sur la structure de quelques diatomees cotenues dans le " $\mathrm{Ce}$ mentstein" du Jutland. Bull. Soc. Belge de Microsc., 11, 147-194.

Saunders, A. D. 1984: The rare earth element characteristics of igneous rocks from the ocean basins. In Henderson, P. (ed.): Rare earth element geochemistry. Dev. Geochem., 2, 205-236.

Saunders, A. D. and Tarney, J. 1983: Geochemical characteristics of basaltic volcanism within back-are basins. In Kokelaar, B. P. \& Howells, M. F. (eds): Marginal basin geology. Spec. Pub. Geol. Soc. Lond., 16, 59-76.

Steiger, R. H. and Jäger, E. 1977: Subcommission on Geochronology: convention of the use of decay constants in geology and cosmocology. Earth Planet. Sci. Lett., 36, 359-362.

Wood, D. A., Joron, J.-L. and Treuil, M. 1979: A re-appraisal of the use of trace elements to classify and discriminate between magma series erupted in different plate tectonic settings. Earth Planet. Sci. Lett., 45, 326-336. 